\title{
KOMPETENCJA INTERKULTUROWA W PERSPEKTYWIE TEORETYCZNEJ I BADAWCZEJ
}

\begin{abstract}
Abstrakt: Kompetencja interkulturowa to zespół zinternalizowanych umiejętności funkcjonowania w sytuacjach komunikacyjnych przebiegających w kontekście wielokulturowości. Kompetencja ta może być rozwijana w trzech obszarach: kognitywnym, afektywnym oraz pragmatyczno-komunikatywnym. Artykuł przedstawia propozycję sposobu diagnozy poziomu kompetencji interkulturowej we wszystkich wspomnianych zakresach.
\end{abstract}

Słowa kluczowe: kompetencja interkulturowa, edukacja międzykulturowa, wielokulturowość

Różnorodność kulturowa jest obecnie doświadczana przez większość społeczeństw. Polska po roku 1945, na skutek eksterminacji wojennej oraz polityki ówczesnych władz, stała się na pewien czas krajem niemalże homogenicznym kulturowo. Zmiana sytuacji politycznej w roku 1989 sprawiła jednak, że obok grup mniejszościowych, zamieszkujących wśród nas od wieków, zaczęło się pojawiać w naszym kraju czasowo lub na stałe coraz więcej osób obcego pochodzenia. Jest to zdaniem J. Nikitorowicza przejaw „nasilających się procesów przemieszczania, migracji, uchodźstwa, łączenia rodzin, peregrynacji motywowanych poznawczo, edukacyjnie, kulturowo, naturalnej ciekawości innych kultur, otwarcia granic itp." (2013, s. 9). Autor podkreśla jednak, że prawidłowo pojmowana wielokulturowość to nie tylko obecność obok siebie różnych kultur, ale „publiczna przestrzeń, w której różne społeczności mogą wchodzić w interakcje, ubogacać się wzajemnie, a także tworzyć nową wspólnotę bez potrzeby rezygnacji z rdzennej tożsamości" (Nikitorowicz 2010, s. 9). Warunkiem optymalnego dla obu stron funkcjonowania w owej przestrzeni jest posiadanie przez nie kompetencji określanych w literaturze mianem międzykulturowych bądź interkulturowych. 


\section{SPOSOBY DEFINIOWANIA KOMPETENCJI INTERKULTUROWEJ}

Najogólniej kompetencję interkulturową (intercultural competence) zdefiniować można za E. Bandurą jako „znajomość podobieństw i różnic między stylami życia i poglądami charakterystycznymi dla różnych kultur oraz umiejętność zastosowania tej znajomości w praktycznej komunikacji” (Bandura 2007, s. 57). Podobne stwierdzenia znajdujemy także u innych autorów, według których jest to kompleksowa umiejętność czy też zespół zinternalizowanych umiejętności funkcjonowania i radzenia sobie w nowych, trudnych przebiegających w kontekście wielokulturowości sytuacjach komunikacyjnych (Aleksandrowicz-Pędich 2006; Mihułka 2012). Osoba kompetentna międzykulturowo dzięki swej ciekawości, otwartości i zdolnościom jest w stanie utrzymywać kontakty z Innymi, przyjąć Ich perspektywę i percepcję świata oraz nie narzucać Innym własnych poglądów i wartości w przekonaniu, że są one jedynie słuszne (Ambrosewicz-Jacobs 2004, s. 70).

W opracowaniu pod redakcją I. Sobieraj wśród przejawów kompetencji międzykulturowej wyszczególnia się m.in.:

- świadomość, że na ludzkie zachowania ma wpływ kultura;

- umiejętność dostrzegania kulturowo różniących się wzorów jako odmiennych od własnych, bez ich oceniania w sposób pozytywny lub negatywny;

- umiejętność identyfikacji własnych standardów kulturowych i oceny ich efektów podczas interakcji z odmienną kulturą;

- rozszerzanie własnych wzorców zachowania kulturowego, a w tym:

- umiejętność zastosowania reguł kulturowych w sposób elastyczny,

- umiejętność adaptacji wybranych norm z innych kultur,

- umiejętność dokonywania racjonalnych kulturowych wyborów w specyficznych sytuacjach;

- angażowanie się w pozytywne związki z ludźmi o innym pochodzeniu kulturowym (Sobieraj 2012, s. 15).

Kompetencje międzykulturowe często definiowane są w literaturze trójczłonowo, przez wyliczenie wiadomości, umiejętności oraz postaw umożliwiających porozumienie z przedstawicielami kultur innych niż własna. Jako przykład można przytoczyć rozważania E. Jastrzębskiej (2005), gdzie w zakresie wiedzy deklaratywnej znajdujemy: wiedzę socjokulturową oraz świadomość (wrażliwość) interkulturową; w zakresie umiejętności interkulturowych: dostrzeganie związków i pośredniczenie między kulturą własną i obcą, radzenie sobie z nieporozumieniami interkulturowymi i wynikającymi z nich konfliktami oraz przezwyciężanie stereotypów, zaś w zakresie postaw - otwartość i zainteresowanie innymi osobami i społecznościami oraz skłonność do relatywizacji własnego kulturowego punktu widzenia. 
Czteroskładnikową koncepcję kompetencji przedstawia B. Dobrowolska, twierdząc, iż wyrażają się one w sferze procesów poznawczych, umiejętności samokontroli i samowychowania, zdolnościach komunikacyjnych i emancypacyjnych (2009, s. 62). Emancypacja powszechnie rozumiana jest jako wyzwolenie i obdarzenie kogoś pełnią praw. W tym przypadku mamy na względzie prawa przedstawicieli innych kultur do egalitarnego traktowania względem kultury określanej mianem dominującej.

W ujęciu E. Bandury (2007) na kompetencję interkulturową składa się aż pięć komponentów. Pierwszy to wiedza o kulturze rodzimej i obcej - znajomość historii obu narodów, realiów współczesnych oraz przyczyn ewentualnych nieporozumień, wynikających np. z różnych konwencji w zakresie komunikacji niewerbalnej. Komponentem drugim są określone postawy, przede wszystkim zaś: otwartość, życzliwość, chęć poznania i zrozumienia oraz gotowość do powstrzymania się od krytycyzmu wobec innej i bezkrytycyzmu wobec własnej kultury. Trzeci składnik to umiejętność interpretacji - objaśniania przejawów obcej kultury i odnoszenia ich do własnej, postrzegania określonych znaczeń z własnego oraz odmiennego punktu widzenia. Składnikiem czwartym jest umiejętność zdobywania wiedzy o kulturze od innych osób, ze źródeł instytucjonalnych i z mediów, zaś ostatnim - krytyczna świadomość kulturowa i obywatelska niezbędna do obserwowania i wyciągania stosownych wniosków.

Kompetencja interkulturowa, niezależnie od niuansów definicyjnych, nie jest, jak podkreśla K. Mihułka, „ani umiejętnością wrodzoną, ani nie można jej w pełni wykształcić, gdyż nabywanie jej to proces długotrwały i dwukierunkowy, który rozpoczyna się podczas pierwszego zderzenia z obcą dla nas rzeczywistością i trwa tak naprawdę do końca naszego życia. KI jest wielkością dynamiczną, zmieniającą się na skutek pozyskiwania nowych informacji, zbierania nowych doświadczeń, odczuć, przeżyć" (2012, s. 108).

\section{SZKIC DO BADAŃ KOMPETENCJI MIĘDZYKULTUROWEJ}

Analiza przedstawionych definicji oraz praktyka edukacyjna wskazują, że kompetencję międzykulturową zasadniczo rozwijamy w trzech obszarach:

1) w obszarze kognitywnym (wiedza o) - przez poszerzanie wiedzy o zagadnienia odnoszące się do aspektów uniwersalnych (np. modele kultury, wymiary, pojęcie szoku kulturowego) jak i o zagadnienia dotyczące specyfiki różnych kultur; istotne są też wgląd we własne preferencje, sposoby zachowań, wyznawane wartości i normy, którymi się kierujemy; 
2) w obszarze afektywnym (emocjonalnym) (postawy i nastawienia) - poprzez zainteresowanie innymi kulturami, otwartość na nie; rozbudzanie empatii; kształtowanie umiejętności radzenia sobie z problemem sprzeczności między własnym systemem wartości a normami typowymi dla innej kultury itp.;

3) w obszarze pragmatyczno-komunikatywnym (wiedza jak) - przez używanie odpowiednich do sytuacji wzorców komunikacyjnych (np. sposoby powitania czy wręczania wizytówek w konkretnych kulturach) oraz skutecznych strategii rozwiązywania konfliktów (Nowicka 2013).

Badanie kompetencji międzykulturowej w świetle powyższych rozważań będzie wymagało zastosowania odpowiednich metod, technik i narzędzi, które pozwolą zdiagnozować poziom wspomnianej kompetencji w trzech wyodrębnionych obszarach.

W przypadku sfery kognitywnej, odnoszącej się do wiedzy respondentów, najodpowiedniejszą techniką diagnostyczną będzie test wiadomości (faktograficzny). Może się on odnosić do czterech wyodrębnionych przez W. Pfeiffera dziedzin kulturoznawstwa, takich jak: krajoznawstwo - wiedza o historii i geografii danego kraju, instytucjach politycznych, gospodarczych i kulturalnych; realioznawstwo - przedstawienie obcej rzeczywistości materialnej, np. pieniądze, przewodniki turystyczne, tablice informacyjne itp.; socjoznawstwo - znajomość zwyczajów, obyczajów, zachowań sytuacyjnych i językowych danej społeczności; kulturoznawstwo sensu stricto - dotyczące wytworów ludzkiego intelektu: literatury, muzyki, malarstwa, architektury itp. (2001). Podobne do opisanego zestawienie kręgów tematycznych zastosowano już w badaniach treści przekazu kulturowego w programach multimedialnych do nauki języka angielskiego. Zaproponowany tam podział wyglądał następująco:

Krąg 1: Obyczajowość - realioznawstwo

a) życie codzienne; b) święta

Krąg 2: Krajoznawstwo

a) aspekt geograficzny; b) aspekt społeczno-historyczny

Krąg 3: Kultura popularna

a) mass media, literatura popularna; b) muzyka popularna

Krąg 4: Kultura wysoka
a) literatura - poezja i proza;
b) sztuka, muzyka klasyczna

Krąg 5: Komunikowanie

a) komunikacja werbalna; b) komunikacja niewerbalna (Nowakowska-Buryła, Joński 2011).

Dobór narodów czy kultur, które należy uwzględnić w badaniach, zależy oczywiście od ich kontekstu - sformułowanych celów i problemów badawczych czy też 
specyfiki zbiorowości respondentów. Jako wskazówkę potraktować można ustalenia J. Błuszkowskiego (2005), który na podstawie specjalnych testów generowania mapy narodów-państw stwierdził, iż w warunkach polskich najwyższą rangę ważności ma 21 narodów, przy czym grupa ta ma charakter zdecydowanie europocentryczny i nie uwzględnia przedstawicieli Afryki, Australii i Ameryki Południowej. Odwołując się do tych przesłanek oraz do informacji o zasobach imigracyjnych w Polsce (www.stat.gov.pl), zestawienie uwzględnionych kultur może wyglądać następująco:

- kultura europejska - kraje skandynawskie / kraje Europy centralnej / kraje Europy południowej;

- kultura amerykańska;

- kultura krajów Bliskiego Wchodu (postrzegana w dużej mierze przez pryzmat religii);

- kultura krajów Dalekiego Wschodu (Japonia, Chiny, Korea, Wietnam);

- kultura Indii i romska.

Badanie dwóch pozostałych obszarów kompetencji interkulturowej wymaga doboru odmiennych metod i narzędzi. Z pewnością duże zastosowanie znajdą tu techniki projekcyjne. Jest to ogólny termin określający test, narzędzie lub zbiór czynności, opracowane w celu dostarczenia informacji o osobowości człowieka lub uzyskania wglądu w jego osobowość przez umożliwienie mu swobodnego reagowania na przedmioty lub sytuacje niezorganizowane lub niejednoznaczne (Reber 2002). Techniki projekcyjne ujawniają treści doświadczenia emocjonalnego i sposoby jego poznawczej strukturyzacji, pozostające w różnym stopniu poza świadomą kontrolą jednostki. Dla ścisłości pojęciowej warto dodać, iż mianem testów projekcyjnych określane są wystandaryzowane narzędzia o sformalizowanym sposobie interpretacji (np. Test Rorschacha, Test Apercepcji Tematycznej, Test Rysunku Postaci), zaś wszelkie inne metody badania oparte na zjawisku projekcji, ale niewymagające ścisłej procedury postępowania nazywamy technikami projekcyjnymi (Stasiakiewicz 2012). Zadania stawiane badanym w narzędziach tego typu pogrupować można na pięć kategorii: (1) skojarzenia, (2) selekcja, (3) uzupełnianie, (4) tworzenie lub (5) ekspresja. D. Maison (1998) stwierdza, że badania technikami projekcyjnymi są szczególnie przydatne w sytuacjach, gdy:

- uczestnik badania może obawiać się wyrażania swoich prawdziwych opinii;

- istnieje obawa, że będzie on odpowiadać tak, by zadowolić osobę prowadzącą wywiad;

- tematyka dotyczy spraw osobistych, tematów drażliwych;

- badana osoba nie zdaje sobie sprawy z rzeczywistych powodów własnego zachowania. 
W przypadku obszaru afektywnego kompetencji można zastosować metodę wolnych skojarzeń. Ma ona podbudowę psychoanalityczną i w zamyśle autorów służyć miała do badania zmiennych trudnych do zmierzenia za pomocą samoopisu. W psychologii klinicznej nie jest ona obecnie stosowana ze względu na małą trafność (Stemplewska-Żakowicz 2011), jednakże może być wykorzystywana jako narzędzie do badań na gruncie pedagogiki czy socjologii. Do badań międzykulturowych polecana jest m. in. przez A. Szczepaniak-Kozak (2007). Metoda wolnych skojarzeń polega na odpowiadaniu pierwszym skojarzeniem na podane słowo-bodziec, np. „Islam”, „uchodźca”. Zarówno bodziec, jak i reakcja mają tutaj postać pojedynczych wyrazów. Analiza uzyskanych odpowiedzi pozwala wnioskować o emocjach badanego względem danego obiektu, zjawiska, sytuacji.

Projekcyjny charakter, choć bardziej strukturalizowaną formę, ma także inna technika - test niedokończonych zdań. Jego istotą jest dopisanie zakończenia do urwanych zdań, np. „U Chińczyków cenię...”, „U Chińczyków nie lubię...”. W przypadku zastosowania komiksowej wersji testu odpowiedzią może być również napisanie w „dymku” co, według osoby badanej, powiedział w określonych okolicznościach bohater obrazka. Podobnie jak metoda wolnych skojarzeń, test zdań niedokończonych ma obecnie zastosowanie głównie w pedagogice i socjologii (Stemplewska-Żakowicz 2011).

Do diagnozy obszaru afektywnego kompetencji interkulturowej można wykorzystać także zadania ukazujące stopień dystansu wobec przedstawicieli innych kultur, skonstruowane w oparciu o skalę dystansu społecznego E. Bogardusa. W odniesieniu do kultury romskiej wyglądałoby to następująco:

1. Czy zgodziłbyś się, aby Romowie mieszkali w twoim kraju?

2. Czy zgodziłbyś się, aby Romowie mieszkali w twojej miejscowości?

3. Czy zgodziłbyś się, aby Romowie mieszkali w twojej dzielnicy?

4. Czy zgodziłbyś się, aby Romowie byli twoimi sąsiadami?

5. Czy zgodziłbyś się, aby twoje dziecko poślubiło Roma?

Im wcześniej zostanie udzielona negatywna odpowiedź, tym dystans społeczny do danej grupy społecznej jest większy.

Inną skalą przydatną do badań jest dyferencjał semantyczny Osgooda. Respondent ocenia dane zjawisko lub określa swój stosunek do niego, sytuując swoją odpowiedź między dwiema skrajnymi pozycjami, zazwyczaj w skali 1-5 lub 1-7, np.:

\begin{tabular}{|l|l|l|l|l|l|l|l|l|}
\hline $\begin{array}{l}\text { Z łatwością podejmuję kontakt } \\
\text { z obcokrajowcami }\end{array}$ & 1 & 2 & 3 & 4 & 5 & 6 & 7 & $\begin{array}{l}\text { z trudnością podejmuję kontakt } \\
\text { z obcokrajowcami }\end{array}$ \\
\hline
\end{tabular}


Skalę tę uwzględnić można w inwentarzu cech przedstawicieli różnych kultur, stworzonym np. w oparciu o zestawienia cech dokonane przez J. Błuszkowskiego (2005). Autor do potrzeb badań wyodrębnił:

- cechy odnoszące się do właściwości psychicznych i charakterologicznych,

- cechy moralne (cnoty i wady),

- cechy mentalnościowe charakteryzujące sposób myślenia, sferę umysłową, przekonaniową i światopoglądową,

- cechy kulturalno-obyczajowe dotyczące kultury osobistej i strefy obyczajowej,

- cechy socjopolityczne odnoszące się do poglądów, postaw i zachowań politycznych,

- cechy socjoekonomiczne określające pozycję i aktywność ekonomiczną,

- cechy relacyjne wyrażające sposoby odniesień i interakcji ludzi z otoczeniem.

J. Błuszkowski, badając stereotypy narodowe w świadomości Polaków, na podstawie analizy frekwencyjnej stworzył profile deskryptywne wybranych narodów. Skonstruowane przez niego narzędzie wyglądało następująco:

\begin{tabular}{|l|l|l|l|l|l|l|}
\hline Cechy negatywne & $\mathbf{1}$ & $\mathbf{2}$ & $\mathbf{3}$ & $\mathbf{4}$ & $\mathbf{5}$ & Cechy pozytywne \\
\hline lekkomyślny & 1 & 2 & 3 & 4 & 5 & rozważny \\
\hline niezdyscyplinowany & 1 & 2 & 3 & 4 & 5 & zdyscyplinowany \\
\hline głupi & 1 & 2 & 3 & 4 & 5 & mądry \\
\hline tchórzliwy & 1 & 2 & 3 & 4 & 5 & odważny \\
\hline nieuczciwy & 1 & 2 & 3 & 4 & 5 & uczciwy \\
\hline podstępny & 1 & 2 & 3 & 4 & 5 & szczery \\
\hline bez honoru & 1 & 2 & 3 & 4 & 5 & honorowy \\
\hline przesądny & 1 & 2 & 3 & 4 & 5 & racjonalny \\
\hline zacofany & 1 & 2 & 3 & 4 & 5 & nowoczesny \\
\hline niekulturalny & 1 & 2 & 3 & 4 & 5 & kulturalny \\
\hline brudny & 1 & 2 & 3 & 4 & 5 & czysty \\
\hline anarchista & 1 & 2 & 3 & 4 & 5 & lojalny obywatel \\
\hline rozrzutny & 1 & 2 & 3 & 4 & 5 & oszczędny \\
\hline leniwy & 1 & 2 & 3 & 4 & 5 & pracowity \\
\hline niegospodarny & 1 & 2 & 3 & 4 & 5 & gospodarny \\
\hline nieżyczliwy & 1 & 2 & 3 & 4 & 5 & życzliwy \\
\hline egoistyczny & 1 & 2 & 3 & 4 & 5 & uczynny \\
\hline
\end{tabular}

Źródło: Błuszkowski 2005, s. 171. 
Przy badaniu ostatniego, pragmatyczno-komunikatywnego obszaru kompetencji interkulturowej można odwołać się do procedur zastosowanych przez Z. Nowaka (2006) podczas diagnozowania kompetencji moralnej dzieci. Wspomniany autor wykorzystał technikę uzyskiwania informacji werbalnych na treść zadań słowno-obrazkowych. Jest ona, jak pisze badacz, „adaptacją znanej i szeroko dyskutowanej metody klinicznej J. Piageta, zwanej też metoda eksploracyjna z wykorzystaniem sytuacji zmyślonych (fabula exempla ficta)" (2006, s. 97). W adaptacji Z. Nowaka osoba badana otrzymuje zestaw 10 zadań słowno-obrazkowych inspirujących do wypowiedzi. Jej zadaniem jest zaprojektowanie oraz uzasadnienie wzorów zachowań w sytuacjach aktywnych kulturowo. W przypadku trudności z wygenerowaniem odpowiedzi (kompetencja czynna) można badać kompetencję bierną, co polega na wskazaniu wśród podanych wzorów zachowań lub uzasadnień tego, które jest adekwatne do sytuacji.

Metoda ta nawiązuje do Testu Apercepcji Tematycznej Murraya, złożonego z tablic przedstawiających sytuacje społeczne o różnym stopniu wieloznaczności. Zadaniem osoby badanej w TAT jest ułożenie opowiadania o tym, co dzieje się na obrazku, zaś interpretacji dokonuje się w ramach analizy sześciu głównych aspektów opowiadań: tematu, głównego bohatera, charakterystyki postaci i zdarzeń; moralnej logiki zdarzeń, struktury wypowiedzi oraz adekwatności poznawczej (Stasiakiewicz 2012). Na podstawie opowieści badacz stara się zrozumieć osobowość autora historii - z kim identyfikuje się, jak postrzega innych ludzi, jak ocenia motywy działania itp. W przypadku badania kompetencji interkulturowej analizowane byłyby jedynie wybrane aspekty wypowiedzi, a zawartość obrazków odnosiłaby się do sytuacji kontaktu $\mathrm{z}$ Innymi.

\section{WNIOSKI}

Badanie kompetencji interkulturowych uczniów, studentów czy osób dorosłych, ich stanu obecnego i dynamiki rozwoju, jest niewątpliwie istotnym i ciekawym poznawczo zadaniem. Wyniki dotychczasowych eksploracji wskazują bowiem na pewną niedojrzałość naszego społeczeństwa w tym zakresie. A. Pasieka, opierając się na materiale badawczym, krytycznie wyraża się o „polskiej wielokulturowości”, twierdząc, że „zakłada (ona) akceptację «innych», ale na ściśle określonych zasadach, które uniemożliwiają naruszenie trzonu kultury dominującej” (2013, s. 137). Autorka zwraca także uwagę, iż w polskim dyskursie publicznych problematyczne jest „nie tylko odbieranie do prawa bycia innym, ale także odbieranie prawa do przynależności do tego, co wspólne" (tamże, s. 137), przy czym zarówno w kultu- 
rze współczesnej, jak i w analizie dorobku historycznego często pomija się wkład etnicznych i religijnych Innych.

Więcej optymizmu wykazuje T. Lewowicki (2011), wskazując na pozytywne symptomy przemian w sferze życia rodzinnego, w szkolnictwie, w placówkach kultury i oświaty pozaszkolnej czy nawet w podejściu do wspólnot religijnych i wyznaniowych. Autor dostrzega jednak wiele trudności, które trzeba jeszcze przezwyciężyć, takich jak chociażby zakorzenione w polskiej świadomości stereotypy czy niski poziom kompetencji międzykulturowych nauczycieli.

Wielokulturowość jest dzisiaj modna i dochodowa. Festiwale, jarmarki, spotkania, projekty unijne często do niej się odwołują, bo jest to opłacalne. Skutkuje to jednak nadużywaniem i spłycaniem tego pojęcia i nie zawsze idzie w parze z rozwojem kompetencji interkulturowych społeczeństwa. Rozwiązanie tego problemu wymaga podjęcia wielotorowych działań, wśród których niezmiernie ważne jest zapewnienie odpowiedniej edukacji międzykulturowej i moderowanie właściwych postaw już u dzieci w wieku przedszkolnym i wczesnoszkolnym, tak by nie bały się kontaktu z Innym, nie patrzyły na osoby odmienne kulturowo jedynie przez pryzmat nabytych w procesie socjalizacji uprzedzeń oraz aby miały wiedzę, umiejętności i pozytywne nastawienie do podejmowania dialogu z Innymi we współczesnym świecie - nazywanym w dobie Internetu „globalną wioską”, ale przecież wioską multikulturową.

\section{LITERATURA}

Aleksandrowicz-Pędich L. (2006). Rozwijanie kompetencji interkulturowej na studiach biznesowych. Propozycje programowe. Wyd. UwB, Białystok.

Ambrosewicz-Jacobs J. (2004). Tolerancja. Jak uczyć siebie i innych. Stowarzyszenie Villa Decius, Kraków.

Bandura E. (2007). Nauczyciel jako mediator kulturowy. Wyd. Tertium, Kraków, s. $58-61$.

Błuszkowski J. (2005). Stereotypy a tożsamość narodowa. Wyd. Elipsa, Warszawa.

Dobrowolska B. (2009). Kompetencje międzykulturowe uczniów jako funkcja rozumienia problematyki wielokulturowości i świadomość jej roli u nauczyciela. Z pogranicza praktyki i teoretycznej refleksji. W: E. Dąbrowa, U. Markowska-Manista (red.). Między kulturami. Edukacja w wielokulturowej rzeczywistości. Wyd. Naukowe ITE PIB, Radom-Warszawa, s. 62.

http://www.stat.gov.pl/cps/rde/xbcr/gus/lud_infor_o_badan_zasob_imigr_pl_w_ 2008.pdf (dostęp: 11.11.2013). 
Jastrzębska E. (2005). Edukacja interkulturowa przyszłych nauczycieli języka francuskiego. „Uniwersytet Zielonogórski” 3.

Lewowicki T. (2011). O doświadczeniach edukacji wielokulturowej oraz perspektywie edukacji i pedagogiki międzykulturowej. W: T. Lewowicki, E. Ogrodzka-Mazur, A. Szczurek-Borut (red.). Edukacja międzykulturowa - dokonania, problemy, pespektywy. Wyd. Adam Marszałek, Cieszyn-Warszawa-Torun.

Maison D. (1998). Testy niedokończonych zdań w badaniach marketingowych. W: K. Stemplewska-Żakowicz (red.). Nowe spojrzenia na Test Niedokończonych Zdań J.B. Rottera. Interpretacja jakościowa. PTP, Warszawa.

Mihułka K. (2012). Sposoby rozwijania kompetencji interkulturowej na lekcji języka obcego. "Języki Obce w Szkole" 2, s. 108.

Nikitorowicz J. (2010). Grupy etniczne w wielokulturowym świecie. Gdańskie Wyd. Psychologiczne, Sopot, s. 9.

Nikitorowicz J. (2013). Kompetencje do komunikacji międzykulturowej $w$ aspekcie tradycyjnej wielokulturowości regionu i procesów migracyjnych. Wprowadzenie w realizowana problematykę. W: J. Nikitorowicz, M. Sobecki, W. Danilewicz, J. Muszyńska, D. Misiejuk, T. Bajkowski (red.). Kompetencje do komunikacji międzykulturowej $w$ aspekcie wielokulturowości regionu i procesów migracyjnych. Wyd. Akademickie Żak, Warszawa, s. 9.

Nowak Z. (2006). Kompetencja moralna jako kategoria teoretyczna i badawcza w pedagogice wczesnoszkolnej. Wyd. Naukowe AP, Kraków.

Nowakowska-Buryła I., Joński T. (2011). Przekaz kulturowy w programach multimedialnych do nauki jezzyka angielskiego dla dzieci w wieku wczesnoszkolnym. W: A. Tyl (red.). Nauczyciel wczesnej edukacji wobec zmieniajacej się rzeczywistości edukacyjnej, kulturowej i społecznej. Wyd. Uniwersytetu Łódzkiego, Łódź.

Nowicka M. Kompetencja międzykulturowa - czym jest, dlaczego powinno rozwijać się ja u pracowników i komu jest potrzebna?, http://www.hrnews.pl/news1. aspx?id=2680 (dostęp: 11.11.2013).

Pasieka A. (2013). Wielokulturowość po polsku. O polityce wielokulturowości jako mechanizmie umacniania Polskości. „Kultura i Społeczeństwo” 3.

Pfeiffer W. (2001). Nauka języków obcych. Od praktyki do praktyki. Wagros, Poznań. Reber A.S. (2002). Słownik psychologii. Wyd. Naukowe Scholar, Warszawa.

Sobieraj I. (2012). Cel i główne założenia metodologiczne badań. W: I. Sobieraj (red.). Kompetencje informacyjno-komunikacyjne i międzykulturowe $w$ gospodarce. Wyd. Naukowe Scholar, Warszawa, s. 15.

Stasiakiewicz M. (2012). Testy projekcyjne. W: J. Strelau (red.). Psychologia. T. 1. GWP, Gdańsk. 
Stemplewska-Żakowicz K, Paluchowski W.J. (2008). J. Strelau, D. Doliński (red.). Podstawy diagnozy psychologicznej. W: Psychologia. Podręcznik akademicki. T. 2. GWP, Gdańsk, s. 23-63.

Stemplewska-Żakowicz K. (2011). Diagnoza psychologiczna. Diagnozowanie jako kompetencja profesjonalna. GWP, Gdańsk.

Szczepaniak-Kozak A. (2007). Zastosowanie metody wolnych skojarzeń w badaniach różnic kulturowych. W: W. Chłopicki (red.). Komunikacja międzykulturowa: perspektywy badań interdyscyplinarnych. Wyd. Tertium, Kraków.

\title{
INTERCULTURAL COMPETENCE: THEORY AND RESEARCH
}

\begin{abstract}
Intercultural competence is the knowledge of similarities and differences between lifestyles and beliefs characteristic of different cultures (nations) and the ability to apply this knowledge in practical communication. This competence can be developed in the following areas: cognitive (knowledge), affective (attitude), and the pragmatic and communication one (behavior). The article shows selected ways of diagnosing the level of this competence in each of these three areas.
\end{abstract}

Key words: intercultural competence, multicultural education, multiculturalism 